Terbit online pada laman web jurnal : http://e-journal.sastra-unes.com/index.php/JIPS

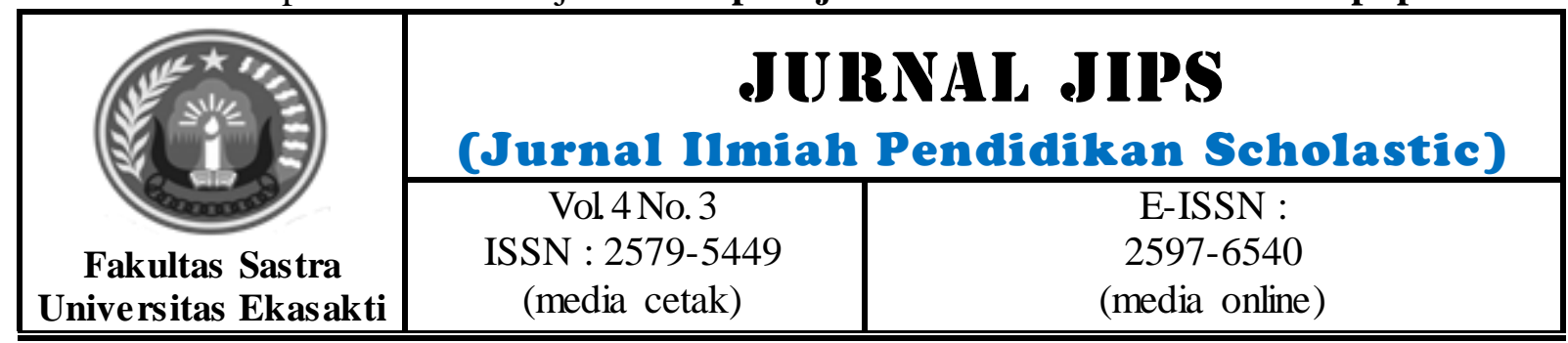

\title{
KORELASI KETERAMPILAN MENULIS TEKS EKSPOSISI DENGAN MOTIVASI BELAJAR SISWA KELAS X SMA EKASAKTI PADANG
}

\author{
Susanti Marisya \\ Program Studi Pendidikan Bahasa dan Sastra Indonesia \\ Universitas Ekasakti
}

Abstract

Penelitian ini dilatarbelakangi oleh rendahnya nilai keterampilan menulis teks eksposisi siswa kelas X SMA Ekasakti Padang dan kurangnya motivasi siswa dalam pembelajaran. Adapun beberapa permasalahan yang ditemukan dalam penelitian ini sulitnya siswa mengembangkan ide dalam menulis teks eksposisi dan kurangnya motivasi belajar siswa dalam menulis teks eksposisi. Penelitian ini bertujuan untuk mengetahui korelasi keterampilan menulis teks eksposisi dengan motivasi belajar siswa kelas X SMA Ekasakti Padang

Jenis penelitian ini adalah kuantitatif dengan metode deskriptif korelasional. Populasi dan sampel dalam penelitian ini adalah siswa kelas X SMA Ekasakti Padang yang berjumlah 22 orang. Teknik pengambilan sampel yang digunakan adalah Purposive Sampling yaitu pemilihan sampel berdasarkan pada karakteristik tertentu yang dianggap memiliki kriteria yang hampir sama dengan populasi yang sudah diketahui sebelumnya. Data penelitian ini adalah skor dari pernyataan angket motivasi belajar yang diisi oleh siswa dan skor dari hasil tes keterampilan menulis teks eksposisi yang telah ditulis oleh siswa. Teknik analisi data menggunakan uji persyaratan analisis, uji normalitas dilakukan dengan Uji Liliefors, uji homogenitas dan analisis uji korelasi product moment dengan bantuan software SPSS(Statistik Product And Service Solution)

Berdasarkan penelitian yang dilakukan dapat disimpulkan bahwa hasil penelitian yang diperoleh sebagaiberikut Pertama, motivasi belajar siswa kelas X SMA Ekasakti Padang berada pada kualifikasi Sedang $(S)$ dengan nilai rata-rata 74,02. Kedua, keterampilan menulis teks eksposisi siswa kelas X SMA Ekasakti Padang berada pada LebihdariCukup (LDC) dengan nilai rata-rata 66.97. Ketiga, berdasarkan hasil uji-t, disimpulkan bahwa terdapat hubungan yang signifikan antara motivasi belajar dengan keterampilan menulis teks eksposisi siswa kelas X SMA Ekasakti Padang karena nilai $t_{\text {hitung }}>t_{\text {tabel }}(2,32>1,72)$ " $t_{\text {hitung }}$ lebih besar daripada $t_{\text {tabel }}$ ". Jadi, dapat disimpulkan bahwa semakin tinggi motivasi belajar siswa akan semakin baik pula keterampilan menulis teks eksposisi siswa tersebut.

Keyword: Keterampilan menulis teks ekspoisisi dan motivasi belajar 


\section{INTRODUCTION}

Mutu pendidikan perlu diperhatikan untuk mencapai tujuan pendidikan, sedangkan mutu pendidikan itu sendiri dapat dilihat dari keberhasilan yang diraih oleh seorang siswa selama mengikuti kegiatan belajar mengajar. Salah satu faktor yang menentukan adalah bagaimana proses belajar dan mengajar dapat berjalan sebagaimana yang diharapkan. Pembelajaran yang bermakna merupakan proses belajar mengajar yang diharapkan bagi siswa di mana siswa dapat terlibat langsung dalam proses pembelajaran serta menemukan langsung pengetahuan tersebut.

Beberapa faktor dapat mempengaruhi belajar baik itu berupa pengaruh positif yang dapat mendukung proses pembelajaran maupun pengaruh negatif yang dapat menghambat proses pembelajaran. Hambatan-hambatan yang terjadi berakibat pada hasil dan proses belajar individu yang tidak sesuai dengan yang hal yang diharapkan. Salah satu faktor yang diasumsikan dapat memberi pengaruh dalam proses pembelajaran yaitu motivasi belajar. Oleh karena itu, guru diharapkan dapat meningkatkan motivasi belajar siswa untuk meningkatkan prestasi belajar siswa. Hal itu sesuai dengan pendapat Dimyati dan Mudjiono (2013:80) motivasi belajar merupakan kegiatan sehari-hari bagi siswa sekolah, karena pada diri siswa terdapat kekuatan mental yang menjadi penggerak belajar".

Salah satu keterampilan berbahasa yang harus dimiliki oleh siswa yaitu keterampilan menulis teks eksposisi. Hal ini sesuai dengan kurikulum 2013 mata pelajaran bahasa dan sastra Indonesia SMA kelas $\mathrm{X}$ semester 1 yaitu pembelajaran menulis teks eksposisi terdapat pada kompetensi Inti (KI) ke-4 menulis, memahami, menerapkan, menganalisis, dan mengevaluasi tentang pengetahuan faktual, konseptual, operasional dasar, dan metakognitif. Adapun yang menjadi kompetensi dasarnya (KD) ke-4.4 mengonstruksi teks eksposisi dengan memperhatikan isi, struktur, dan kebahasaan.

Teks Eksposisi merupakan salah satu ragam teks yang memiliki tujuan memberikan informasi, menyampaikan, menjelaskan, menguraikan sesuatu hal yang dapat menambah pembaca. Selain itu, struktur teks eksposisi harus ditulis dengan jelas dan benar karna dengan penulisan yang sesuai maka tujuan teks ekspoisi akan sesuai dengan yang diharapkan penulis serta pesan yang disampaikan penulis akan mudah dipahami oleh pembaca. Hal ini sesuai dengan Akhadiah, dkk (dalam Dalman 2016:119) teks eksposisi adalah "suatu corak teks yang menerangkan atau menginformasikan sesuatu hal yang memperluas pandangan, wawasan atau pengetahuan pembaca".

Berdasarkan observasi yang dilakukan terhadap siswa, terdapat beberapa faktor yang menjadi kendala dalam pembelajaran menulis yaitu kurangnya motivasi belajar siswa dalam menulis teks eksposisi dan sulit mengembangkan ide atau wawasan dalam menulis teks eksposisi. Mengembangkan ide memang sulit dilakukan oleh siswa hal ini terlihat ketika memulai menulis mereka banyak yang tidak mampu dan menganngap menulis sebagai beban. Sementara itu, motivasi belajar pun kurang, hal ini terlihat ketika siswa diberikan tugas banyak siswa yang mengeluh, disaat jam pelajaran banyak siswa yang tidak fokus belajar ada yang sering keluar masuk, ada yang tidur-tiduran, ada yang main hp, dan ada yang ribut.

Berdasarkan fenomena di atas maka penelitian mengenai Korelasi Keterampilan Menulis Teks Eksposisi dengan Motivasi Belajar Siswa Kelas X SMA Ekasakti Padang penting untuk dilakukan. Adapun tujuan dalam penelitian ini adalah untuk mengetahui dan mendeskripsikan korelasi keterampilan menulis teks eksposisi dengan motivasi belajar siswa kelas X SMA Ekasakti Padang.

\section{RESEARCH METHOD}

Jenis penelitian ini penelitian kuantitatif. Sementara itu, metode penelitian yang diterapkan adalah metode deskriptif korelasional. Menurut Arikunto (2010:215) deskriptif korelasional adalah "suatu penelitian yang dirancang untuk menentukan tingkat hubungan variabel-variabel yang berbeda dalam suatu populasi yang bertujuan untuk mengetahui seberapa besar 
kontribusi variabel $(\mathrm{X})$ terhadap variabel $(\mathrm{Y})$ serta bentuk hubungan yang terjadi. Penelitian ini bertujuan untuk mengetahui seberapa besar korelasi yang terdapat pada keterampilan menulis teks eksposisi variabel terikat (Y) dengan motivasi belajar sebagai variabel bebas (X) siswa kelas X SMA Ekasakti Padang.

Populasi dalam penelitian ini merupakan seluruh siswa kelas X SMA Ekasakti Padang. Pengambilan sampel dalam penelitian ini dilakukan dengan metode Purposive Sampling. Purposive Sampling merupakan "pemilihan sampel berdasarkan pada karakteristik tertentu yang dianggap mempunyai sangkut paautnya dengan karakteristik populasi yang sudah diketahui sebelumnya" (Rosady, 2008:157). Maka dipilih beberapa kelas yang dianggap dapat mewakili berdasarkan penelitian, atau kenyataan yang terjadi sebelumnya yaitu kelas X IPS 3 . Instrumen yang digunakan dalam pengumpulan data ada dua macam yaitu berbentuk tes untuk mengukur keterampilan teks eksposisi siswa dan angket untuk mengukur motivasi belajar siswa.

Adapun langkah-langkah pengumpulan data berupa tes menulis teks eksposisi adalah sebagai berikut (1) menjelaskan teori eksposisi dan memberikan contoh teks eksposisi (2) Siswa ditugaskan untuk menulis teks eksposisi dengan menggunakan dua tema yang telah ditentukan. (3) Melihat sejauh mana kemampuan siswa dalam menulis teks eksposisi berdasarkan indikator dengan menggunakan rubrik penilaian.
Sementara itu, Langkah-langkah pengumpulan data berupa angket dilakukan dengan cara (1) Memberikan angket pada siswa. (2) Siswa ditugaskan mengisi angket. (3) Memeriksa dan menentukan skor hasil yang telah dikerjakan oleh siswa. Selanjutnya, teknik analisis data yang dilakukan dalam penelitian ini adalah melakukan uji persyaratan analisis yang meliputi uji normalitas, uji homogenitas, dan uji hipotesis. Uji normalitas bertujuan untuk melihat apakah sampel berdistribusi normal atau tidak. Uji normalitas dilakukan dengan Uji Liliefors dengan ketentuan apabila nilai signifikan > 0,05 maka data berdistribusi normal dan apabila nilai signifikan < 0,05 maka data tidak berdistribusi normal. Uji homogenitas, untuk mengkaji apakah kedua data tersebut homogen, yaitu dengan membandingkan kedua variansnya dengan ketentuan, taraf signifikan $(\alpha)=0,05$. Jika $F_{\text {hitung }}>$ $F_{\text {tabel }}$ homogen, dan jika $F_{\text {hitung }} \leq F_{\text {tabel }}$ berarti tidak homogen. Uji hipotesis, yaitu (1) Korelasi Regresi Linear Sedeharna

dapat dihitung nilai korelasi antara $\mathrm{X}$ dan Y, yaitu sebagai berikut.

$r x y=\frac{N \sum x y-\left(\sum x\right)\left(\sum y\right)}{\sqrt{\left\{N \sum x^{2}-\left(\sum x\right)^{2}\right\}\left\{N \sum y^{2}-\left(\sum y\right)^{2}\right\}}}$

(2) Uji t digunakan untuk mengetahui apakah model regresi variabel independen secara parsial berpengaruh signifikan terhadap variable dependen

\section{RESULTS AND DISCUSSION}

Pada hasil penelitian ini akan dijelaskan sebagai berikut. Hasil menulis teks eksposisi siswa kelas X SMA Ekasakti. Hasil/ skor angket motivasi belajar siswa Kelas X SMA Ekasakti Padang. Korelasi keterampilan menulis teks eksposisi dengan motivasi belajar siswa kelas $\mathrm{X}$ SMA Ekasakti Padang.

Data keterampilan menulis teks eksposisi diperoleh melalui tes unjuk kerja. Dalam tes tersebut siswa diminta untuk menulis sebuah teks eksposisi dengan tema yang telah ditentukan. Setelah data terkumpul, data tersebut kemudian diberi skor berdasarkan indikator yang dinilai. Indikator yang dimaksud, yaitu mengungkapkan (a) berisi pendapat, gagasan, keyakinan, (b) memerlukan analisis dan sintesis, (c) menggali

sumber ide dari pengalaman, (d) menggunakan bahasa informatif, dan (d) berisi penegasan. Penilaian untuk setiap aspek menggunakan skala $0-3$. Setelah data dikoreksi diperoleh skor tertinggi adalah 13 dan skor terendah adalah 8 . Skor maksimal yang harus diperoleh siswa adalah 15.

Perolehan skor keterampilan menulis teks eksposisi siswa kelas X SMA Ekasakti Padang secara lengkap sebagai berikut. Pertama, skor 13 diperoleh oleh 2 orang siswa $(9,09 \%)$. Kedua, skor 12 diperoleh oleh 3 orang siswa $(13,63 \%)$. Ketiga, skor 11 diperoleh oleh 2 orang siswa $(9,09 \%)$. Keempat, skor 10 di peroleh oleh 6 orang siswa $(27,27 \%)$.Kelima, skor 9 diperoleh

Jurnal JIPS (Jurnal Ilmiah Pendidikan Scholastic) Vol. 4 No. 3 (2020) ISSN : 2579-5449

This work is licensed under a Creative Commons Attribution-NonCommercial 4.0 International License. 
oleh 5 orang siswa $(22,73 \%)$. Keenam, skor 8 diperoleh oleh 4 orang siswa $(18,18 \%)$.

Perolehan skor/ nilai motivasi belajar siswa kelas X SMA Ekasakti Padang dijelaskan seperti berikut ini. Nilai tertinggi yang diperoleh siswa adalah 88,33 dan nilai terendah adalah 66,67. Gambaran motivasi belajar siswa kelas X SMA Ekasakti Padang secara umum. Pertama, siswa yang memperoleh nilai motivasi belajar dengan kualifikasi Tinggi Sekali (TS) berjumlah 3 orang $(13,64 \%)$. Kedua, siswa yang memperoleh nilai motivasi belajar dengan kualifikasi Tinggi (T) berjumlah 4 orang $(18,18 \%)$. Ketiga, siswa yang memperoleh nilai motivasi belajar dengan kualifikasi Sedang (S) berjumlah 15 orang $(68,18 \%)$. Selanjutnya dilakukan uji hipotesis. Namun, sebelum dilakukan uji hipotesis terlebih dahulu dilakukan uji normalitas dan uji homogenitas.

Berdasarkan uji normalitas yang dilakukan untuk keterampilan menulis teks eksposisi diperoleh nilai $\mathrm{L}_{0}=-0,3268$ dan $\mathrm{L}_{\mathrm{t}}=0,188$ pada taraf nyata 0,05 untuk $\mathrm{n}=22$. Dikarenakan $\mathrm{L}_{0}<$ $\mathrm{L}_{\mathrm{t}}(-0,3268<0,188)$ dapat disimpulkan bahwa data berdistribusi normal. Selanjutnya, uji normalitas yang dilakukan untuk motivasi belajar, diperoleh nilai $\mathrm{L}_{0}=-0,1668$ dan $\mathrm{L}_{\mathrm{t}}=$ 0,188 pada taraf nyata 0,05 untuk $\mathrm{n}=22$. Dikarenakan $\mathrm{L}_{0}<\mathrm{L}_{\mathrm{t}}(-0,1668<0,188)$ dapat disimpulkan bahwa data berdistribusi normal. Sementara itu, Uji homogenitas data dilakukan dengan menggunakan rumus perbandingan varian terbesar dengan varian terkecil dengan menggunakan derajat kebebasan $\mathrm{n}-2$ dan taraf nyata 0,05 pada tabel Distribusi $\mathrm{F}$ terbaca batas signifikansi $\left(\mathrm{F}_{\text {tabel }}\right)$ adalah 2,09. Mengingat $\mathrm{F}_{\text {hitung }}$ 1,48 lebih kecil dari $F_{\text {tabel }}$ 2,09 maka dapat disimpulkan bahwa kedua varians tersebut homogen.

Korelasi keterampilan menulis teks eksposisi siswa dengan motivasi belajar siswa kelas X SMA Ekasakti Padang dilihat dengan menggunakan rumus korelasi product moment. Data variabel bebas memiliki hubungan yang linear dan berarti dengan variabel terikat karena $r_{\text {hitung }}>r_{\text {tabel }}(0,462>0,423)$. Berdasarkan nilai $r$ yang diperoleh, diketahui bahwa nilai korelasi kedua variabel dalam penelitian ini adalah 0,462. Selanjutnya dilakukan uji $\mathrm{t}$ untuk menafsirkan keberartian hubungan antara kedua variabel. Hasil dari uji t adalah 2,32.

Berdasarkan hasil pengujian hipotesis tersebut, dapat disimpulkan bahwa terdapat korelasi antara motivasi belajar dengan keterampilan menulis teks eksposisi pada taraf nyata 0,05 dengan derajat kebebasan $\mathrm{n}-2(22-2=$ 20). Berdasarkan hal tersebut, berarti terdapat korelasi antara keterampilan menulis teks eksposisi siswa dengan motivasi belajar siswa kelas X SMA Ekasakti Padang. $\mathrm{H}_{0}$ dalam penelitian ini ditolak, sedangkan $\mathrm{H}_{1}$ diterima karena hasil pengujian membuktikan bahwa $t_{\text {hitung }}$ lebih besar dari $t_{\text {tabel }}$ yaitu 2,32 $>1,72$.

Berdasarkan uraian tersebut, dapat disimpulkan bahwa terdapat korelasi yang signifikan antara keterampilan menulis teks eksposisi siswa dengan motivasi belajar siswa kelas X SMA Ekasakti Padang. Hal ini berarti bahwa motivasi belajar yang tinggi akan membuat keterampilan menulis teks eksposisi siswa semakin baik. Sejalan dengan hal tersebut, Wahab (2016:131) mengemukakan bahwa salah satu fungsi motivasi dalam belajar yaitu sebagai penggerak perbuatan. Dorongan psikologis yang melahirkan sikap terhadap anak didik itu merupakan suatu kekuatan yang tak terbendung yang kemudian terjelma dalam bentuk gerakan psikofisis. Dorongan inilah yang menjadi penggerak siswa dalam menulis teks eksposisi.

dari Cukup (LDC) dengan nilai rata-rata 66,97. Ketiga, berdasarkan hasil uji-t, disimpulkan bahwa terdapat hubungan yang signifikan antara keterampilan menulis teks eksposisi siswa dengan motivasi belajar siswa kelas X SMA Ekasakti Padang karena nilai $t_{\text {hitung }}>$ $t_{\text {tabel }}(2,32>1,72) \quad$ " $t_{\text {hitung }}$ lebih besar daripada 
$\mathrm{t}_{\text {tabel }}$ ". Jadi, dapat disimpulkan bahwa semakin tinggi motivasi belajar siswa akan semakin baik pula keterampilan menulis teks eksposisi siswa tersebut.

Berdasarkan simpulan tersebut, maka ada beberapa saran bagi beberapa pihak yaitu kepada guru mata pelajaran bahasa Indonesia khususnya guru kelas X SMA Ekasakti Padang untuk lebih meningkatkan motivasi belajar siswa.
Hal ini disebabkan karena motivasi belajar berhubungan erat dengan keterampilan menulis teks eksposisi. Siswa, terutama siswa kelas $\mathrm{X}$ SMA Ekasakti Padang untuk lebih banyak berlatih menulis karena dengan latihan akan mempermudah siswa mengembangkan ide dalam menulis. Peneliti lain sebagai masukan dan perbandingan dalam melakukan penelitian yang berkaitan dengan masalah ini. 


\section{Bibliography}

[1]Alwasilah, A. Chaedar. 2005. Pokoknya Menulis. Bandung: PT. Kiblat Buku Utama.

[2]Anwar Suroyo. 2009. Pemahaman Individu, Observasi, Checklist, Interviu, Kuesioner, dan Sosiometri. Yogyakarta: Pustaka Pelajar.

[3]Arikunto, Suharsimi. 2010. Prosedur Penelitian Suatu Pendekatan Praktik. Jakarta: Rineka Cipta.

[4]Dalman, 2016. Ketrampilan Menulis. Jakarta: Rajawali Pers.

[5]Depdiknas. 2006. Metode Pembelajaran Bahasa Indonesia. Jakarta: Depdiknas.

[6]Djamarah, Syaiful Bahri. 2008. Psikologi Belajar. Jakarta: Rineka Cipta.

[7]Gani, A Ramlan. 2014. Suka Berbahasa Indonesia. Jakarta: Gaung Prasada Press Group.
[8]Hamalik, Oemar.2013. Proses Belajar Mengajar. Jakarta: PT Rineka Cipta.

[9]Manizar, Ely. 2005. Pengantar Psikologi Pendidikan. Palembang: IAIN Raden Fatah Press.

[10]Rani Abdul dkk. 2006. Analisis Wacana. Malang: Bayumedia.

[11]Riduwan. 2008. Dasar-dasar Statistika. Bandung: Alfa Beta.

[12]Sugiyono.2006. Metode Penelitian Kuantitatif, Kualitatif dan $R$ \& D. Bandung: Alfabeta.

[13]Uno, Hamzah. 2012. Teori Motivasi dan Pengukurannya, Jakarta: Bumi Aksara.

[14]Wahab Rohmalina . 2016. Psikologi Belajar. Jakarta: Rajawai Pers. 